\title{
Selection of reference gene in Eucalyptus camaldulensis for real-time qRT-PCR
}

\author{
Boby Unnikrishnan*, Gurumurthy Demlapura Shankaranarayan, Navin Sharma \\ From IUFRO Tree Biotechnology Conference 2011: From Genomes to Integration and Delivery \\ Arraial d'Ajuda, Bahia, Brazil. 26 June - 2 July 2011
}

\section{Background}

Real time quantitative reverse transcription PCR (realtime qRT-PCR) is an established technique for quantification of mRNA and has been extensively used for gene regulation studies in plants. However, there are inherent challenges associated with the technique such as variability of RNA and extraction protocols, different rates of reverse transcription and PCR efficiencies. This demands an accurate method of normalization to obtain reproducible results. Among the various methods, normalization to a reference house keeping gene is the most commonly used method. If inappropriate reference genes are used for normalization, the experimental results can vary significantly leading to false results [1].

Eucalyptus camaldulensis Dehnh. is a widely distributed tree species used for planting in arid and semi-arid areas. The wood is composed of mainly cellulose and lignin and the pathway involved in lignin formation is fairly understood. The lignin biosynthetic genesviz Ferulate 5 Hydroxylase (F5H), 4 Coumarate CoA Ligase (4CL), Cinnamoyl CoA Reductase (CCR) and Cinnamoyl Alcohol Dehydrogenase (CAD) are highly conserved across the tree species and have been utilized as targets for manipulating lignin content. The present study describes validation of a reference gene in various tissue types of eucalyptus and its subsequent use for the expression analysis of lignin biosynthetic genes.

\section{Materials and methods}

Samples were collected from three different tissues of E. camaldulensis namely xylem, young leaf and mature leaves and three developmental stages viz one, one and half and three years. The samples were named as $\mathrm{X}$ (1-3) for all the xylem samples coming from three developmental stages and $\mathrm{Y}(1-3)$ and $\mathrm{M}(1-3)$ for young leaves

\footnotetext{
* Correspondence: bobyunni@rediffmail.com

Division of Plant Molecular Biology, ITC R\&D Centre, Bangalore 560058, India
}

and mature leaves respectively (Figure 1). Total RNA was extracted with RNAqueous Kit (Ambion, Austin TX, USA) following manufactures protocol. cDNA was synthesized from $1 \mu \mathrm{g}$ of RNA using High Capacity cDNA Reverse Transcription Kit (Applied Biosystems, Foster City, CA, USA) with random hexamer primers. Primers for house keeping genes and lignin biosynthetic genes were designed based on the EST data from Eucalyptus using Primer Express 3.0 Software (Applied Biosystems). The nucleotide sequence of $C A D, C C R, 4 C L$ and $F 5 H$ from $E$. camaldulensis were deposited in NCBI database (HR309064, HR309065, HR309066, HR309067). The real time PCR efficiency of each primer pair was determined with the slope of a linear regression model and all PCRs displayed efficiencies between 90 and 95\%. Comparative $\mathrm{C}_{\mathrm{T}}$ method was followed for quantification of lignin biosynthetic genes with $18 \mathrm{~S}$ rRNAas the internal control as suggested by Schmittgen and Livak [2]. The stability analysis of each reference gene was carried out by the method given by Brunner et al. [3].

\section{Results}

The choice of internal control is usually straight forward especially for analysis of samples from same tissues. However, when samples are derived from different tissues or developmental ages, as it is seen in our study, required validated reference gene/ genes. Six different housekeeping genes were chosen for the analysis which included NADP isocitrate dehydrogenase, $18 \mathrm{~S}$ ribosomal RNA, Histone H4, 60S ribosomal protein L7, Translational initiation factor (TIF) and Glyceraldehyde 3 phosphate dehydrogenase. Among the genes used in the study, $18 \mathrm{~S}$ rRNAshowed the least $\mathrm{C}_{\mathrm{T}}$ indicating higher abundance while the highest $C_{T}$ was observed for TIF. Further, 18S rRNA showed maximum stability when $C_{T}$ was plotted against samples (Figure 1). A gene with low stability index is considered to have highest stability [3]. 


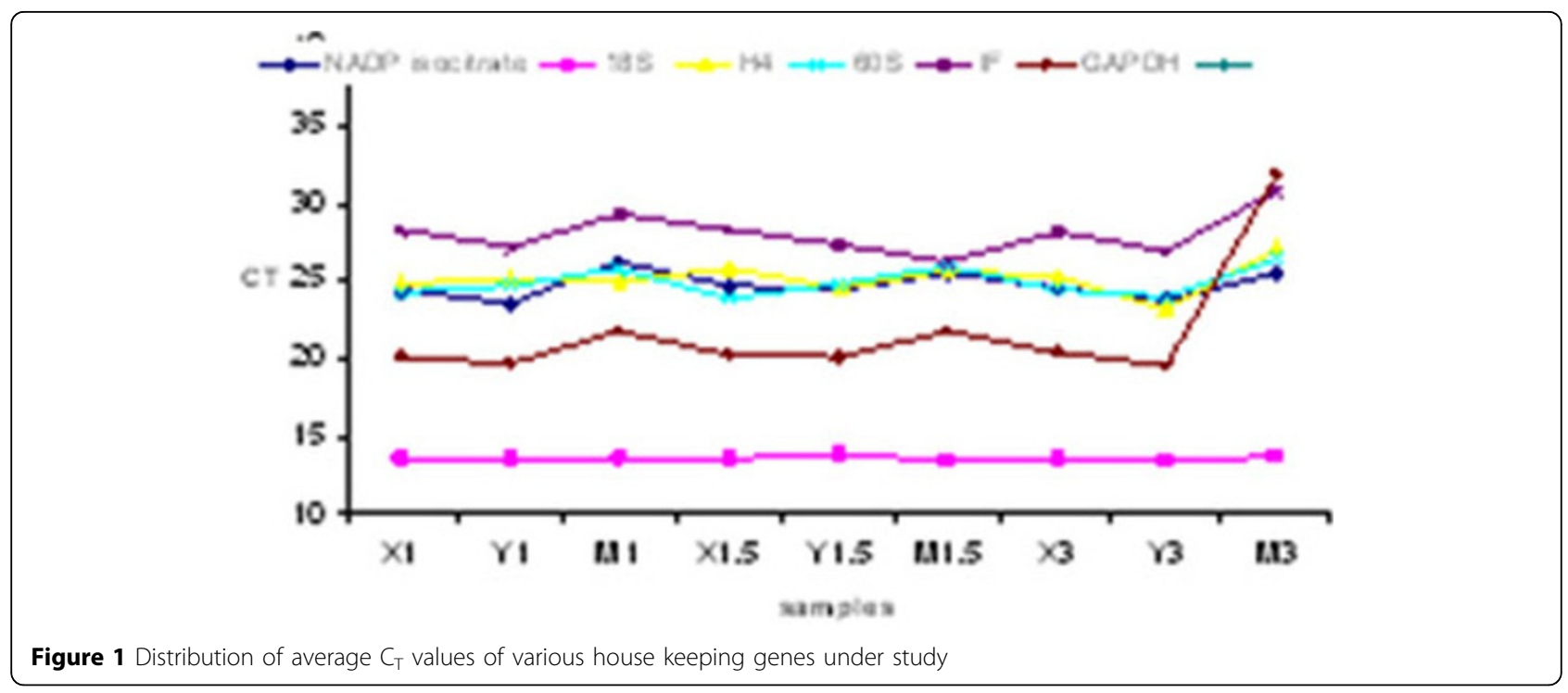

In the present study with E. camaldulensis, $18 \mathrm{~S}$ rRNA had the lowest stability index while GAPDH showed maximum variation among the samples.

Expression analysis of four lignin biosynthetic genes viz CCR, CAD, F5H and $4 C L$ were carried out in different samples by using $18 \mathrm{~S}$ rRNA as the reference gene. Lignin analysis of samples showed higher lignin content in three-year-old samples estimated by klason lignin analysis compared to one-year old. All genes under study showed increased expression in three year old samples except for $C A D$ gene. The results also showed increased amount of $\mathrm{F} 5 \mathrm{H}$ transcripts in older tissues indicating higher syringyl units in older tissue. Chen et al. [4] reported syringyl type lignin content and S/G ratio increased from younger internode to older internode while $G$ and $H$ decreased in parallel.

As the expression profile showed variations in different age samples, further experiment was under taken to evaluate the expression levels of these genes in same age trees (Three year old) in correlation with lignin content. Based on klason lignin content, trees with lignin content of $26 \pm 0.3$ and $24 \pm 0.2 \%$ were chosen for the studies. All genes under study viz4CL, CAD, CCR and F5H showed increase in expression in high lignin sample in comparison with low lignin.

\section{Conclusions}

Among the house keeping genes under study, 18SrRNA exhibited lowest stability index and we are suggesting it as a reference gene for expression studies in Eucalyptus. The reduction in $C A D$ transcript level and higher levels of $F 5 H$ in older tissues indicated a possible shift towards an increased syringyl lignin where as when analysis was done at same age, expression levels of all selected lignin biosynthetic genes were high in high lignin tree. The study opens up the possibility for using these genes as candidate genes for the selection of desired genotypes.

\section{Acknowledgements}

The first author would like to thank Ramadevi P for lignin analysis and Girisha $\mathrm{R}$ in helping in statistical analysis.

Published: 13 September 2011

\section{References}

1. Dhelda K, Hugget JF, Chang JS, Kim LU, Bustin SA, Johnson MA, Rook GA, Zumla A: The implications of using an inappropriate reference gene for real time reverse transcription PCR data normalization. Anal Biochem 2005, 344:141-143.

2. Schmittgen TD, Livak KJ: Analyzing real-time PCR data by the comparative $C_{\mathrm{T}}$ method. Nature Prot 2008, 3:1101-8.

3. Brunner MA, Yakovlev IA, Strauss SH: Validating internal controls for Quantitative plant gene expression studies. BMC Plant Biol 2004, 4:14.

4. Chen L, Auh C, Chen F, Cheng X, Aljoe H, Dixon RA, Wang Z: Lignin deposition and associated changes in anatomy, enzyme activity, gene expression and ruminal degradability in stems of tall fescue at different developmental stages. J Agric Food Chem 2002, 50:5558-5565.

\section{doi:10.1186/1753-6561-5-S7-P125}

Cite this article as: Unnikrishnan et al:: Selection of reference gene in Eucalyptus camaldulensis for real-time qRT-PCR. BMC Proceedings 20115 (Suppl 7):P125.

\section{Submit your next manuscript to BioMed Central and take full advantage of:}

- Convenient online submission

- Thorough peer review

- No space constraints or color figure charges

- Immediate publication on acceptance

- Inclusion in PubMed, CAS, Scopus and Google Scholar

- Research which is freely available for redistribution 